\title{
Can we teach morality without influencing the worldview of students?
}

\author{
Jacomijn C. van der Kooij ${ }^{1,2}$ • Doret J. de Ruyter ${ }^{1}$ • \\ Siebren Miedema ${ }^{1,3}$
}

Published online: 19 May 2016

(C) The Author(s) 2016. This article is published with open access at Springerlink.com

\begin{abstract}
The central question in this article is whether teaching morality necessarily means paying attention to 'worldview'. We investigate a conceptual and a justificatory relationship between these two. A distinction is made between organised and personal worldview and between narrow and broad morality. Some schools want to avoid influence on the students' views based on organised worldviews they adhere to. This is not always possible. The article explains why. It demonstrates that that when one teaches broad morality, attention is paid to the personal worldview of students. Finally, the article discusses the implications of our analysis for reflections on education.
\end{abstract}

Keywords Broad morality $\cdot$ Narrow morality $\cdot$ Organised worldview $\cdot$ Personal worldview $\cdot$ Relationship worldview and morality

\section{Introduction}

A few years ago, one of the authors worked as a Religious Education consultant in primary education. One of the tasks of such a consultant is to assist teachers and principals in the process of formulating the religious identity of their schools. During one

Jacomijn C. van der Kooij

jvanderkooij@verus.nl

Doret J. de Ruyter

d.j.de.ruyter@vu.nl

Siebren Miedema

s.miedema@vu.nl

1 Faculty of Behavioural and Movement Sciences, Theory and Research in Education, VU University Amsterdam, Amsterdam, The Netherlands

2 Verus, Association for Catholic and Christian Schools in the Netherlands, Woerden, The Netherlands

3 Faculty of Theology, Department of Praxis, VU University Amsterdam, Amsterdam, The Netherlands 
of the meetings with a team of teachers working at a school whose population had changed from homogeneously Christian to multi-religious, one of the teachers raised a challenging issue. She said, 'In the course of our day, I am teaching children about several world religions, we have to stimulate them in their personal development, teach and live by certain norms and values, and pay attention to citizenship and morality. These seem to be so much related, that it seems impossible to do the one without doing at least bits of the other as well'.

The teacher seems to be right: religious education, personhood formation and moral education overlap in theory, and in practice they cannot be separated. But this answer is not specific enough. The question requires a more sophisticated and precise response, because some schools have to or want to avoid a direct influence on their students' views and beliefs about meaning giving and existential notions, (their worldview), while in most countries schools are required to provide moral and citizenship education. Moreover, it is theoretically of interest to clarify the distinction and overlap between worldview (education) and morality (moral education) if only because this enables empirical researchers and politicians to be precise in their reflections.

The central question of this article is therefore: if we teach morality, do we then necessarily pay attention to worldview as well?

Our answer to the central question will be based on the analysis of two types of relationships between morality and worldview. Firstly, we will explore a conceptual relationship: Can we speak about 'morality' without speaking about 'worldview'? In other words, is the use of the concept 'worldview' a necessary condition for the use of the concept of 'morality'?' Secondly, we will also examine a justificatory relationship: do moral claims need to refer to worldview for their justification? Before we look into these two questions, we will first give a concise description of the two terms 'worldview' and 'morality'.

\section{Conceptual clarifications: 'worldview' and 'morality'}

\subsection{Worldview}

As a concept, 'worldview' is used in various ways. ${ }^{2}$ In everyday speech it is sometimes used as an equivalent for religion, and sometimes as a general outlook on the world. We believe that the former is too limited and the latter too comprehensive. The advantage of using 'worldview' instead of 'religion' lies in the fact that, given the increase in societal individualism and the plurality of views on life present in current western societies, we need a concept more encompassing than 'religion'. 'Worldview' can achieve this purpose. We do, however, not use the concept worldview for the general outlook on the world because it is not distinctive enough. We use worldview for a more specific outlook on the world, namely one that is focused on meaning giving and existential themes.

\footnotetext{
1 When we look into a conceptual relationship, we do not pay attention to empirical facts, we only look at how concepts are related to each other. One might state that a conceptual analysis does not do justice to the messiness of (in this case: moral) life. It is, however, not the aim of our conceptual analysis to formulate empirical standpoints based on empirical findings. The aim is conceptual clarification.

2 'Worldview' is used in various research domains as well. For instance in anthropology, in which it is often related to the concept 'culture' (Kluckhohn and Strodtbeck 1961), in psychology (Koltko-Rivera 2004; Solomon et al. 1991; Ibrahim et al. 2001), and in the philosophy of science (Kuhn 1969).
} 
Sometimes these meaning giving and existential views are part of a more or less coherent and established system that has developed over time with certain (written and unwritten) sources, traditions, values, rituals, ideals or dogmas. It constitutes a group of believers who adhere to this view on life. We call this an organised worldview. Paradigmatic examples of organised worldviews are religions. Every religion is an organised worldview. Christianity includes for instance certain rituals, sources, traditions and dogmas. But not every organised worldview is a religion. Non-religious examples are Humanism or Communism. ${ }^{3}$ Humanism does not have fixed rituals but it does have certain ideals, sources and values that are shared by a group of people who consider themselves Humanists. Communism also has certain ideals and values and also has specific traditions like commemorations important to people calling themselves Communists (Van der Kooij et al. 2013).

In a previous article in Religious Education (2013), we analysed necessary characteristics of an organised worldview. We concluded that an organised worldview prescribes ${ }^{4}$ answers to existential questions; they also contain moral values and aim to answer the question about the meaning of life. In this way, it aims to influence people's thinking and actions.

The concept 'worldview' can also be used to describe someone's personal meaning giving outlook on the world, life and humanity. A personal worldview can be, but is not necessarily, based on or inspired by an organised worldview. If someone calls himself a Christian, for example, his personal worldview will be more or less influenced by the organised worldview of Christianity. If someone calls himself a Communist he will base his views on for instance Marx's or Lenin's ideas. Many people do not construct their own personal worldview on the basis of one specific organised worldview. A personal worldview can be more eclectic and idiosyncratic than an organised worldview (Van der Kooij et al. 2013; compare Hartman 1986; Aadnanas 1992, cited in Sandsmark 2000; Hijmans 1997; De Jong 1998). Reasons for this include the increase of societal individualism and the awareness of individuals of a variety of organised worldviews as a result of globalisation. This makes it possible for individuals to pick elements of a diversity of worldviews to build their own worldview. These 'bricoleurs', as Hervieu-Leger (2006) calls them, use aspects like words and symbols from different traditions to construct a personal religious profile. Someone can go to church regularly, meditate with Hindu affirmation and take the idea of mindfulness seriously in all aspects of his or her life.

Our description of personal worldview was: A personal worldview consists of (sometimes tentative) answers to existential questions. Someone's personal worldview influences his thinking and acting and gives meaning in life (Van der Kooij et al. 2013).

Two characteristics that we pointed out in our descriptions of organised and personal worldview need further explanation in order to answer our central question. The first is the aspect of existential questions. These questions will be the subject of the next section. The second is the aspect of moral values, which will be discussed in the following section.

\footnotetext{
3 In a previous article (Van der Kooij et al. 2013) we stated that political theories are not worldviews. A political theory is a description of ideas and explanations of how a state should be run, including topics such as the (rule of) law, justice and the way in which citizens participate. Communism as a worldview answers existential questions. This will be explained in the remainder of this section.

${ }^{4}$ Not every source that addresses existential notions is an organised or personal worldview, however. Scholarly books about existential notions do for instance not necessarily express a certain worldview. They describe the questions and notions.
} 


\subsubsection{Existential questions}

Existential questions have a special status in people's lives. They reach a profound level, the essence of someone's life, and move beyond situations and actions in the here and now (Van der Kooij et al. in press; Tillich 1965). In an analysis which we conducted on literature about 'worldview', we found that 'existential questions' are part of almost all of the descriptions of worldviews (Van der Kooij et al. 2013, in press). Some authors explicitly refer to existential questions, stating that certain questions are 'existential' or 'ultimate'. Other authors do not use the term 'existential questions', but give examples of questions in their texts about worldview, sometimes in a scattered way or embedded in descriptions of specific worldviews, that are of an existential nature. In our analysis we used both the explicit and implicit descriptions of existential questions. On the basis of this analysis we were able to compile a list of existential questions a worldview deals with.

1. Ontological questions We found two types of such questions. The first focuses on the nature of existence: Why is there something rather than nothing? (e.g. McKenzie 1991; Sandsmark 2000; Sire 2004). A second type of ontological questions focuses on the nature of a human being, which can also be called anthropological questions: What is a human being? Is human nature good or bad? (e.g. Walsh and Middleton 1984, Aadnanes 1992 cited in Sandsmark 2000, p. 6).

2. Cosmological questions This category contains questions about the origin and nature of the universe and the place of human beings in it (e.g. McKenzie 1991; Smart 2000, Aadnanes 1992 cited in Sandsmark 2000; Sire 2004). Is the cosmos a divine creation? Is the evolution of living creatures into human beings a coincidence? (Smart 2000).

3. Theological questions Is there a god? Are there many gods? What is the nature of this god or these gods? (e.g. Brümmer 1981; McKenzie 1991; Sire 2004; Aadnanes 1992 cited in Sandsmark 2000; Smart 2000; Miedema 2006).

4. Teleological questions Here we also found two types of questions. The first focuses on the meaning and purpose of the universe and human beings (e.g. Walsh and Middleton 1984; McKenzie 1991; Hijmans 1994, 1997; Miedema 2006; Valk 2007). The second focuses on the meaning in life. Where the 'meaning of life' deals with an understanding of the purpose of (human) life in general; the 'meaning in life' is a personal interpretation of what makes life meaningful and what gives an individual's life purpose or sense (De Ruyter 2002).

5. Eschatological questions This type deals with questions such as: what happens when a person dies? Is there life after death? Will we reincarnate? (e.g. Brümmer 1981; Aadnanes 1992 cited in Sandsmark 2000; Hijmans 1994, 1997; Miedema 2006; Sire 2004).

6. Ethical questions The questions and values in this category have to do with the broad theme of good and bad, right and wrong (Walsh and Middleton 1984; Hijmans 1994, 1997; Miedema 2006; Sire 2004; Valk 2007). 'What makes my life a good life to live?' is part of this category, as are questions about beauty and truth.

It is not necessary for a personal or organised worldview to pay attention to all of these questions. A personal or organised worldview can have answers to some questions, reflect on others, without paying attention to others. This might be truer for a personal worldview than an organised worldview. However, to be able to say that someone has a worldview, (s)he should at least have (tentative) answers to the first, fourth and sixth question. 


\subsection{Morality}

'Morality' and 'ethics' have already been mentioned in relation to 'worldview' in the course of this article.

As we made clear, we use 'ethical' to describe the category of existential questions dealing with values concerned with the broad theme of 'the good life'. 'Morality' can be regarded as a subcategory: it is often used for matters regarding the well-being of others. It can be conceptualised as the acts (and their underlying rules or principles, the character required) that are right or good to other (groups of) people, other sentient species or the environment, as well as the avoidance of acting in ways that harm them or human coexistence (Gert 2016). Answers to moral questions, conceptualised in this way, are part of organised worldviews. All paradigmatic examples of organised worldviews contain certain moral ideas about how people should act in relation to others' well-being and ideas about right and wrong. Buddhism has for instance the Eightfold Path, while Humanism harbours the belief that all people are equal and should have equal opportunities. A personal worldview does not necessarily include moral answers in this way. It can be predominantly morally indifferent. Imagine for instance a person whose decisions in moral situations are not based on the well-being of others but on other intrinsic reasons related to for instance aesthetics or epistemology. In a situation where the well-being of another is at stake, this person will not ask: 'What is beneficial for this other person?' but 'What brings about the most beauty?' or 'What brings me closer to finding truth?'. This person has a personal worldview, albeit a morally indifferent or a-moral, one. ${ }^{5}$

This does, however, not answer our main question whether it is possible to teach morality without paying attention to worldview. That morality is part of 'organised worldview' does not mean that we can only teach morality within the context of teaching an organised worldview. Furthermore, to answer our main question and get a more complete picture of the domain of worldview and morality, we need to be more precise in describing morality.

\subsubsection{Morality: narrow and broad}

It is helpful to make a distinction between two dimensions of morality: narrow morality and broad morality (e.g. Mackie 1977; Musschenga 1980). Narrow morality focuses on the basic rules and principles that make it possible for human beings to live and work together-it is the morality that is necessary for the continuation of every tolerable society (Mackie 1977). Its purpose is to protect people's basic interests other than the actor's by inhibiting certain forms of behaviour. Narrow morality is about duties and obligations to others. Examples of basic rules that are part of narrow morality are the ban on robbing or killing other people.

Broad morality focuses on living a flourishing life and surpasses moral rules necessary to live together. Broad morality contains the body of ideals, principles and values that indicate someone's most important aims in life, which influence their acts for realizing these aims and give meaning in life (Mackie 1977; De Jong 1998; De Ruyter 2006). Broad morality comprises more than the basic rules and principles necessary for social life: it also encloses matters that make someone's life meaningful. Examples of matters that can be included in a broad morality are aesthetic values or values with regard to living a healthy

\footnotetext{
5 Morally indifferent is not the same as immoral. A personal worldview would be immoral if it contains ideas and beliefs that are contrary to the wellbeing of other people.
} 
life. Finally, broad morality can focus on others but also on the self. For instance, it may include values such as kindness and generosity, while also regarding what makes life meaningful for an individual.

To answer our main question, the distinction between narrow and broad morality is crucial, as will be demonstrated in the next section of the article.

\section{The relationship between worldview and morality conceptually explored}

This section examines the conceptual relationship between worldview and morality. De Jong (1998) distinguishes three manners in which this relationship can be conceived. Firstly, morality and worldview are conceptually independent of each other. In this case, a worldview does not determine the content of morality, or to put it differently: answers to existential or meaning giving matters do not determine the answers to questions about what is morally right or good. Secondly, the relationship between the concepts can be described as dependent. In this view, the concept 'worldview' is a necessary condition for the concept 'morality'. When one uses the concept 'morality', one necessarily refers to 'worldview' as well. Answers to existential questions determine the answers to what is morally right or good. The third and final view states that the concepts overlap; they partly share the same conceptual domain. A worldview can partly determine the moral views one has, but a worldview does not determine all of the moral views and vice versa.

We will now further analyse how the conceptual relationships between narrow and broad morality on the one hand and organised and personal worldview on the other can be described in terms of De Jong (1998).

\subsection{Narrow morality and organised and personal worldview conceptually explored}

To speak about 'narrow morality' is it necessary to refer to organised or personal worldview? We can speak about the basic rules and obligations making it possible for human beings to live and work together without the necessity of speaking of or referring to a particular organised or personal worldview. Minimal moral rules focus on human welfare, the human condition, and do not include normative views about the good life. The answers to existential questions do not determine the answers to matters regarding narrow morality. The conceptual relationship between narrow morality on the one hand and organised or personal worldview on the other can be described as 'independent' in De Jong's (1998) terms. 'Personal worldview' and 'organised worldview' are no necessary conditions in order to speak about 'narrow morality'.

\subsection{Implications for reflections on education}

Since narrow morality comprises the values that are necessary for living together, it will inevitably be part of education and school life. For schools to fulfil their role of educating and teaching, it is necessary that certain rules, for instance rules that ban physical violence and sanctify the possessions of others, are obeyed by students and staff. Thus, education will always need to pay attention to narrow morality. 
This can happen in two ways. Firstly, it can be an explicit and special part of the curriculum. Teachers can, for instance, take time to clarify and discuss why narrow moral values are important, and they can teach specific narrow moral values to the students. Secondly, narrow morality will be part of the school's rules and its ethos. The school's rules that should be obeyed by everyone, the way students and staff interact, how conflicts are resolved, and other mores of the school all articulate at least narrow morality.

As narrow morality is conceptually independent from organised or personal worldview, narrow morality can be part of the school curriculum and of its ethos, without a necessary reference being made to organised or personal worldview. Questions such as 'Does society need honest people?' or 'Are bullying and discrimination morally wrong?', can be the subject of a classroom discussion by referring to general human well-being instead of specific answers to anthropological, eschatological, theological or ethical questions of an organised or personal worldview.

\subsection{Broad morality and organised and personal worldview conceptually explored}

Broad morality and worldview are conceptually related, but how? We can speak about broad morality without speaking about organised worldview. Broad morality may contain ideals, values and principles that are not part of an organised worldview. For instance, 'views on the earth's sustainability' contain both ecological and fair trade principles. Although it is consistent with views from certain organised worldviews (e.g. vegetarianism in Hinduism, human dignity in Humanism and stewardship in Christianity), being part of an organised worldview is not a necessary condition for this broad morality. Organised worldviews on the other hand always do contain broad moral views: ideals, principles and values. When speaking about 'organised worldview' one speaks about 'broad morality' at the same time. But when one speaks about 'broad morality', one does not necessarily speak about 'organised worldview'.

As has become clear from the descriptions, personal worldview and broad morality are conceptually close to each other. Someone's ideals, principles and values indicating their most important aims in life, influencing their actions in the realisation of these aims and giving meaning in life are closely related to the existential questions or notions of his or her worldview. Thus the relationship cannot be described in terms of independence, but is 'personal worldview' a necessary condition for 'broad morality' or is there a conceptual overlap between the two terms? Conceptual overlap would mean that a 'personal worldview' would determine some broad moral views, while other aspects are independent of 'personal worldview'. 'Broad morality' is made up of two categories of the existential questions that we compiled. Firstly, ethical matters refer to living a good life. Broad morality contains the ethical values a person has. Secondly, broad morality includes more than ethical matters, as the meaning giving aspect of the definition indicates. Broad morality includes teleological questions as well. But not all teleological questions are part of broad morality. While notions about meaning in life, i.e. a personal interpretation of what makes life meaningful and what gives an individual's life purpose or sense, are always part of someone's broad morality, teleological notions about the meaning of life, which deal with an understanding of the purpose of (human) life in general, are not necessarily part of someone's broad morality. One's views on the meaning of life does not have to refer to broad morality. The ideals someone has do not necessarily say something about the meaning of life, nor do their beliefs about the meaning of life necessarily tell us something about their ideals. One can have an idea about the meaning of human life, e.g. 
Fig. 1 Personal worldview

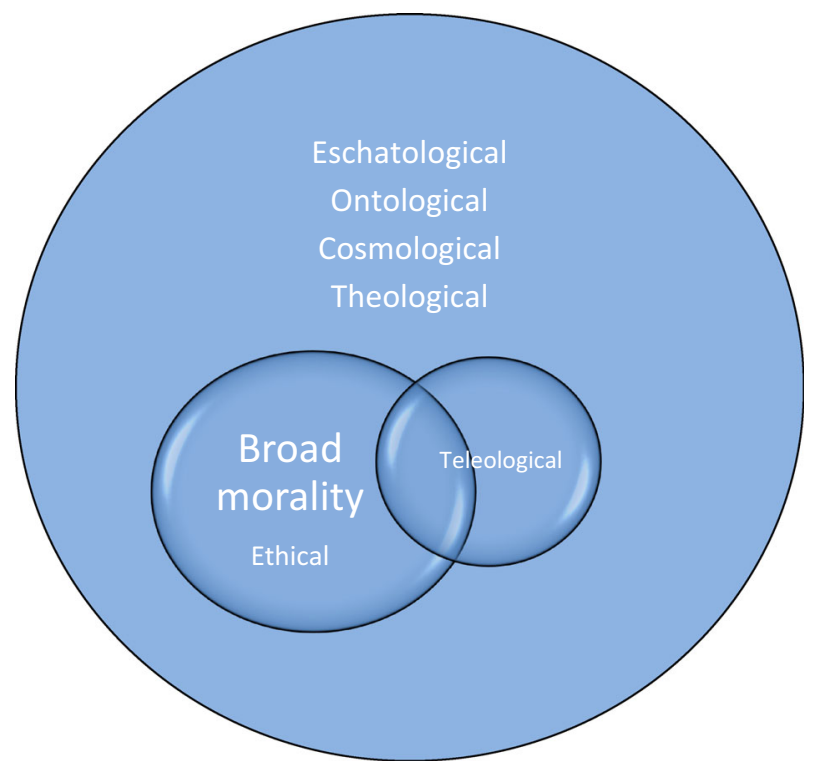

that it is a coincidence and does not have meaning, without this belief determining what gives meaning in life, for instance doing one's work well and having a good relationship with one's loved ones.

Ethical and teleological notions are part of people's personal worldview and broad morality is part of someone's personal worldview as well. But the personal worldview includes more than just these constitutive parts. The other categories of existential questions (the theological, ontological, cosmological and eschatological notions) are part of the personal worldview but not part of the broad morality which is also included. This is explained in the Fig. 1 below.

Thus, we can state that because ethical and certain teleological questions are part of both broad morality and personal worldview, 'personal worldview' is a necessary condition for 'broad morality'. When one speaks about 'broad morality', one necessarily speaks about 'personal worldview' as well.

\subsection{Implications for reflections on education}

We stated that narrow morality is conceptually independent of both organised and personal worldview. Teaching rules that are part of narrow morality therefore does not mean that one teaches a worldview. However, it is interesting or possibly complicating that this might be precisely an educational aim. Teachers want students to act morally right in the narrow sense because they see the value of narrow morality and not for instance, the fear of punishment. They aim for intrinsic motivation in students to act according to narrow morality. They want the narrow morality to become part of their personal worldview.

Schools can pay attention to broad morality in various ways. In the first place, schools can teach into views that are part of broad morality and a corresponding life aim. Pupils are expected to acquire an established (component of) broad morality as part of their own broad morality. An example is a Christian school aiming to teach into this worldview or a 
Waldorf school teaching a holistic Steinerian based broad morality. It is likely that in such schools the broad morality presented is a respective part of the Christian or Steinerian worldview. Secondly, schools can teach about various broad moralities or components of broad moralities. Broad moralities that are part of an organised worldview as well as broad moralities of a bricoleur type can be used as examples to be studied and discussed. Finally, educators can stimulate the development of students' own broad morality. Students are stimulated to reflect on what makes their lives worthwhile, what they find most important in their lives and, subsequently, which ideals, principles and values guide them in the realisation of this aim. An example of this is the use of positive psychology in classrooms (Seligman et al. 2009). It stimulates students to reflect upon what they find important in life and its underlying ideals, values and principles.

We stated that 'organised worldview' is not a necessary condition for 'broad morality'. Teachers can teach into, talk about or stimulate students to reflect upon broad morality without speaking about 'organised worldview'. However, as has been stated above, organised worldviews form examples par excellence of views that include these broad moralities, and teachers can, therefore, use them as examples.

We described the way how broad morality and personal worldview partly comprise the same conceptual domain: someone's broad morality is part of his or her personal worldview. This overlap has several implications for education. If schools choose to present a (diversity of conceptions of) broad morality, for example, because they believe that this contributes to adequate personhood formation and to the flourishing of their students, they thereby also pay attention to the personal worldview of their students. When students are asked to reflect on the principles, ideals and values that are part of their broad morality, they are at the same time stimulated to reflect on (parts of) their personal worldview-and this might be a worldview that is based on a particular organised worldview. Thus, in the situation that students have a personal worldview based on a particular organised worldview, 'organised worldview' is not only an educational topic in schools based on a particular organised worldview (e.g. Christian schools, Steinerian schools), but also in schools not based on a particular organised worldview that want to pay attention to the concept of broad morality as well.

\section{The relationship between worldview and morality in terms of justification}

When exploring the justificatory relationship we ask whether one needs to refer to organised or personal worldview to justify broad or narrow moral claims. We have not found research about the justificatory relationship between worldview and morality. The justificatory relationship between religion and morality, however, has been the subject of research (see for instance Frankena 1973; Musschenga 1980; Kole 2002) and we will use the three main views about this relationship in analysing the relationship between worldview and morality. Firstly, the dependency thesis on the relation between religion and morality states that morality is dependent on religion for its justification. Ideas and actions can only be morally right when an authority, a god, a scripture or a religious leader, declares them to be morally right. When we translate this into organised and personal worldview this means that the moral views a person has, will always be justified by his or her personal worldview.

Secondly, the thesis of strong autonomy rejects the idea that religion is relevant for morality. Morality can and should do without religion for justification. Moral reasons should be separated from religious reasons, and the latter should take no part in moral 
reasoning and justification. An example of a philosopher who defends this strong autonomy view is Frankena (1973). According to him, morality should be objective and universal, and this can only be the case when autonomous people are free to judge, use rational thinking and base their judgements on the same information about a certain moral situation (Frankena 1973; Kole 2002). Since religious beliefs are not universally accepted by all autonomous people, the condition of 'the same information' cannot be fulfilled and thus religion cannot be used to justify moral claims. When we translate this into worldview, it means that people's organised and personal worldview cannot be a justification for morality because they are not universally accepted.

And thirdly, the thesis of weak autonomy states that religion can be used for the justification of moral claims, but this is not necessary. People can appeal to religious reasons for the justification of moral claims without requiring every other person to make this appeal in the same situation as well. For instance, one can justify the belief that it is our moral duty to share with people who have less by referring to the Christian principle of loving one's fellow human being, while someone else might justify it by referring to general principles of humanity. Furthermore, a person can justify some moral claims by referring to religion, but does not have to do so for all moral claims he or she makes. This thesis seems plausible on the one hand because there is ample empirical evidence that nonreligious people can act morally right, just like religious people. This supports the idea that religion and morality do not necessarily depend on each other. On the other hand the thesis is also plausible because people sometimes justify their moral acts with religious reasons (Kole 2002). When we translate this into worldview, this means that sometimes moral claims are justified by referring to organised or personal worldviews, and that they sometimes are justified without any reference to organised or personal worldviews.

It should be noted that there is a difference between the first two theses and the last one. The dependency thesis and the strong autonomy thesis are normative: they state that a moral claim only has moral status when it does or does not use worldview for its justification. The weak morality thesis is descriptive and empirical: it states that sometimes people justify moral claims by their worldview and sometimes they do not. This thesis corresponds with reality, what most people experience in their lives, and therefore seems to be the most credible one of the three.

In what follows, we will first look at narrow morality and its relationship to worldview, both organised and personal, then at the relationship between broad morality and worldview, both organised and personal.

When we describe the relationships with personal worldview, we do this from the perspective of a person who has a personal worldview to which he or she refers for justification.

\subsection{Narrow morality and organised and personal worldview explored in terms of justification}

Sometimes an organised worldview is used as a justification for narrow morality. Often, communities that adhere to an organised worldview will refer to this organised worldview for justifying narrow moral claims. For example, Buddhist communities might refer to the Eightfold Path when stating why violence is forbidden, and Jewish communities might refer to the Torah and the Ten Commandments when explaining why stealing is morally wrong. Not only do communities based on an organised worldview do this, individuals do as well. 'I believe lying is wrong because The Moral Code of the Builder of Communism 6

\footnotetext{
${ }^{6}$ A set of 12 rules made by the Communist Party of the USSR in 1961.
} 
states that we should make sure that we are honest' or 'I won't commit adultery, because the Qur'an states in the 17th Chapter that this is not good'.

What can we say about the relationship between personal worldview and narrow morality in terms of justification? Characteristic for the rules that belong to narrow morality is that they can be justified without reference to a particular personal worldview. Their justification can be of an instrumental nature with regard to the interaction with others. For instance the possibility to cohabit: If everyone were to steal, society would become unliveable. Their justification can also consist in the self-interest of people themselves: If I keep my promises, it is likely that others will keep their promises towards me too. It is the reverse of the idea of reciprocity which states that one should not harm others, because one does not want to be harmed oneself, which can also be given as the justification of narrow morality. Another form of self-interest is people justifying narrow moral claims by stating that these are the rules of society and that if they do not conform, there would be some kind of sentence or penalty.

A personal worldview can of course be used as a justification for narrow morality. In justifying narrow moral claims, like the prohibition to kill or violate the rights or integrity of other people, many people will ultimately refer to existential notions like the ethical principle of the value of human life.

Thus the relationships between narrow morality and personal worldview can be described as weakly autonomous. Personal worldviews can be used as a justification for narrow morality, but other justifications, like the ones mentioned above, can be given as well.

\subsection{Implications for reflections on education}

In schools based on a certain organised worldview, it is to be expected that school boards, principals and teachers, have views on and express to students the relationship between narrow morality and this organised worldview. However, in class situations, it is likely that other justifications are given by teachers as well, especially justifications that refer to the well-being of others. For instance, instead of a teacher stating, 'We do not hit each other because God does not agree with that', or 'we do not hit because it does not agree with the Steinerian views on respect for people', she might state, 'We do not hit each other because it hurts people'.

Schools not based on an organised worldview, can explain what certain organised worldviews state with regard to narrow morality, but they will not use these statements as justifications for narrow morality. Thus, we notice a formal difference between denominational and non-denominational schools in terms of justifying narrow morality, but in practice the difference is probably less obvious.

Teaching narrow morality in schools does not only aim to influence students' behaviour, but their beliefs and dispositions as well. Teachers want their students' ethical principles and values (and thus their personal worldview and broad morality) to be in line with narrow morality and thus intrinsically motivating them to be moral in the narrow sense. Narrow moral views are then justified by the students' personal worldview.

We stated that organised and personal worldviews can also be used to justify narrow moral views, but not necessarily. Students can give various other justifications for their narrow moral claims. One needs to be aware that students are still developing their personal views and the manner in which they justify their moral views. They refer for instance to preventing punishment or conforming to social examples set by friends or family. For instance, in a class discussion about property and ownership, a young child can state that taking his or her friend's pen is wrong because the teacher will be angry. 


\subsection{Broad morality, organised worldview and personal worldview: explored in terms of justification}

We described broad morality as the body of ideals, principles and values that indicate someone's most important aims in life, determine the acts for their realisation and that give meaning in life. Organised worldviews contain broad moral views. It is likely that communities that adhere to a certain organised worldview will refer to this worldview to justify their broad moral claims. This is also true for personal worldviews.

If we recall the conceptual relationship between worldview and morality (Fig. 1), we can see that broad morality is part of personal worldview. It contains the existential notions about ethics and teleology. These notions are about what someone believes to be part of the essence of his life (see the description of 'existential questions' above). The justification needs to refer to someone's intrinsic values. Two kinds of justification can be given. Firstly, the ideals, values and principles constitutive for someone's broad morality can also serve as a justification for this broad morality. The value of hospitality, for instance, can serve as a justification for the ideal of contributing to people living a happy life by being welcoming, attentive and kind. Secondly, the other existential notions (the theological, eschatological, ontological, cosmological and some teleological matters) can serve as a justification for broad moral claims. The theological belief in a god or gods for instance, can justify the broad moral belief that developing a relationship with this god or these gods is the most important aim of a someone's life.

To summarise, broad morality can be justified either by elements of personal worldview that are not part of broad morality itself (e.g. cosmological or theological views) or by ideals, principles or values (ethical and partly teleological views) that are part of broad morality itself (Fig. 2).

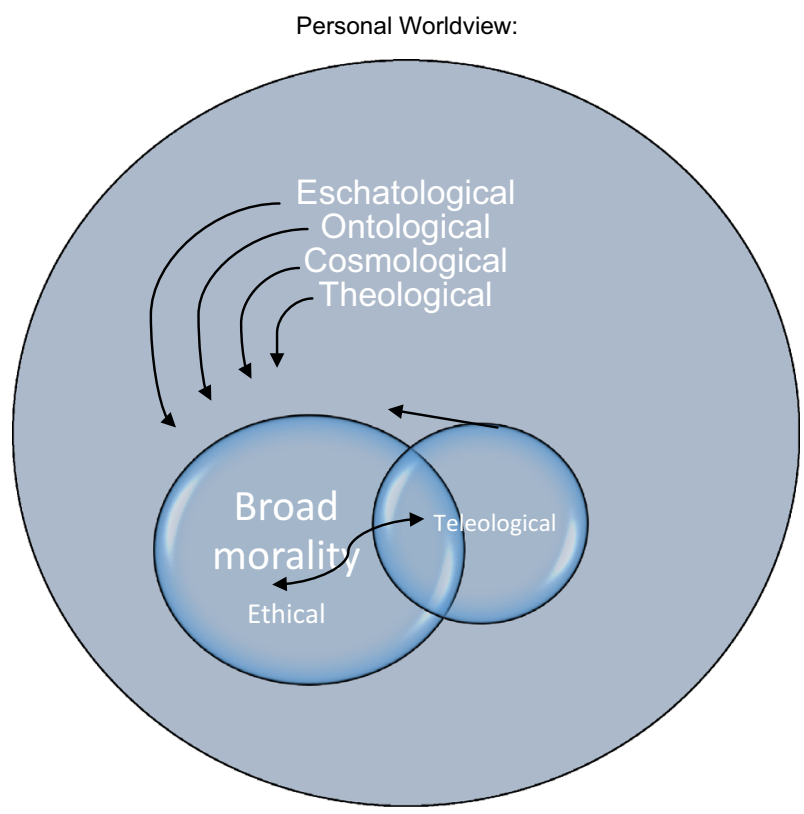

Fig. 2 Justifying broad morality. The black arrows indicate how broad morality can be justified 


\subsection{Implications for reflections on education}

What do the relationships described above between broad morality on the one hand and organised and personal worldview on the other hand mean for the educational context?

It seems very difficult for educators not to pay attention to broad morality at all. Situations often occur in school life that are related to broad moral notions: a fancy fair to collect money for a charity, lessons about fair trade or projects to make the school more ecological. These matters will be part of the classroom discussion and will stimulate students to reflect on the reasons why they are important. This means that broad morality will somehow always be part of education.

We stated that broad morality needs justifications referring to reasons that someone believes to be valuable for her or himself. Primary school children's justifications often refer to friends, family or people they admire (although this can be true for older students and even adults): 'I am a vegetarian because my friend is one'. If students are stimulated by teachers and by each other to reflect on their own principles and ideas, two things may happen: Firstly, personal reasons such as existential ideas and meaning giving views from their personal worldview may become more important for the justification of broad moral claims: 'I am a vegetarian because I believe that animals do not differ so much from human beings, and they have a soul as well'. Secondly, the student discovers that he or she might not agree with the narrow or broad moral views of family and friends after all.

We also stated that broad morality can be justified either by elements of personal worldview that are not part of broad morality itself (e.g. cosmological or theological views) or by ideals, principles or values that are part of broad morality itself. For instance, when students discuss their wishes for the future they may mention: becoming rich, world peace, becoming a famous singer, saving nature, helping the poor, becoming a writer and being happy. The student who announces that she wants to become a writer can justify her life aim by stating that writing makes her feel good, she likes reading herself, and she wants others to find pleasure in her stories. These ideas are part of her broad morality. Other existential notions are, however, not mentioned in the justification. Someone else may justify his wish that humans stop destroying nature by stating that the world is beautiful because God created it, and humans were placed on it to look after it. This student does refer explicitly to other existential notions, theological and cosmological, that are part of his personal worldview.

\section{Summary and concluding thoughts}

How does our analysis help to answer our main question: 'If we teach morality in education, do we then necessarily pay attention to worldview as well'? In the conceptual analysis of the relationship between broad and narrow morality, it has become clear that narrow morality is conceptually independent of both organised and personal worldview. Teaching rules that are part of narrow morality therefore does not mean that one teaches a worldview. We can speak about broad morality without speaking about organised worldview. This is not possible, however, for broad morality and personal worldview. Broad morality is conceptually part of personal worldview. The educational aim of developing students' broad morality will thus always mean that attention is paid to the formation of (a part of) their personal worldview. 
The justificatory analysis of the relationship between worldview and morality demonstrates that for narrow morality and personal worldview, the justificatory relationship can generally be described in terms of weak autonomy. This means that narrow morality is not necessarily justified by referring to personal worldview, but that students can refer to their personal worldview to justify moral claims. The relationship between broad morality and personal worldview can be described as a dependent one. The part of personal worldview that we call 'broad morality' needs justifications that refer to reasons a person believes to be of intrinsic value herself. Personal worldview is necessarily involved in justifying broad morality. When students are stimulated by teachers and each other to formulate such reasons, the existential and meaning giving views from their personal worldview might become more important for justifying broad moral claims. Thus, when attention is paid to the justification of broad morality in education, one refers to personal worldview.

We also found that organised worldviews can be used to justify narrow and broad morality, but not necessarily. When attention is paid in schools to narrow or broad morality without directly paying attention to organised worldview matters, this does not mean that the personal views of pupils that are part of organised worldviews are not influenced. When students learn about, discuss and agree with certain broad or narrow moral views, this might have an impact on the beliefs of the organised worldview they adhere to. Their views based on an organised worldview might for instance no longer be able to justify new broad or narrow moral claims. Thus, although some schools want to or have to avoid an influence on the organised worldviews their students agree with, this might not always be possible due to the justificatory relationship between organised worldview and broad or narrow morality. For instance, a student might have learned at home that abortion is wrong because life is created by God. In a class discussion about this topic, classmates' opinions can influence his views on abortion and he or she can start questioning the justification the organised worldview gives for viewpoints on this topic and the viewpoint itself.

By briefly giving examples of how the results of our analysis are applicable in the classroom, we have already demonstrated how practically important our theoretical analysis is for teachers. As we saw in the example of the teacher from the introduction of this article: it is not always exactly clear what is happening in schools, and teachers are not always sure which role they have in matters such as the formation of broad morality and personal worldview. Teachers should be aware of the close relationship between personal worldview and broad morality. Our analysis shows that the development of students' personhood formation need not happen exclusively in denominational schools. Teachers at non-denominational schools who believe that paying attention to this development contributes to the flourishing of students, can, through moral education in the broad sense, stimulate the personal worldview development of their students.

This close relationship between personal worldview and broad morality is also interesting for policymakers. Schools in England for example are required to pay attention to the moral development of their students. Ofsted, for instance, wrote in the document Promoting and evaluating pupils' spiritual, moral, social and cultural development (2004) that 'Moral development is about the building, by pupils, of a framework of moral values which regulates their personal behaviour' (p. 15). Both narrow and broad morality provide such a framework. When policy makers take into account the above analysis, they can formulate more precisely what they mean by 'moral education', what the implications are of narrow and broad moral education and what choices schools have in teaching moral education. 
Open Access This article is distributed under the terms of the Creative Commons Attribution 4.0 International License (http://creativecommons.org/licenses/by/4.0/), which permits unrestricted use, distribution, and reproduction in any medium, provided you give appropriate credit to the original author(s) and the source, provide a link to the Creative Commons license, and indicate if changes were made.

\section{References}

Brümmer, V. (1981). Theology and philosophical inquiry: An introduction. London: Macmillan.

De Jong, J. M. (1998). Waardenopvoeding en onderwijsvrijheid. Ph.D. Dissertation. Nijmegen: Katholieke Universiteit Nijmegen.

De Ruyter, D. J. (2002). The right to meaningful education: The role of values and beliefs. Journal of Beliefs and Values, 23(1), 33-42.

De Ruyter, D. J. (2006). Be ye perfect? Religious ideals in education. Journal of beliefs and Values, 27(3), 269-280.

Frankena, W. (1973). Is morality logically dependent on religion? In G. Outka \& J. P. Reeders (Eds.), Religion and morality (pp. 295-317). Garden City: Achor Books.

Gert, B. (2016). The definition of morality. Stanford Encyclopedia of Philosophy.

Hartman, S. (1986). Children's philosophy of life. Malmö: CWK Gleerup.

Hervieu-Léger, D. (2006). In search of certainties: The paradoxes of religiosity in societies of high modernity. The Hedgehog Review, 8(1-2), 59-68.

Hijmans, E. J. S. (1994). Je moet er het beste van maken: een empirisch onderzoek naar hedendaagse zingevingssystemen. PhD Dissertation. Nijmegen: Katholieke Universiteit Nijmegen.

Hijmans, E. J. S., \& Smaling, A. (1997). Over de relatie tussen kwalitatief onderzoek en levensbeschouwing: een inleiding. In A. Smaling \& E. J. S. Hijmans (Eds.), kwalitatief onderzoek en levensbeschouwing (pp. 12-31). Amsterdam: Boom.

Ibrahim, F. A., Roysircar-Sodowsky, G., \& Ohnishi, H. (2001). Worldview: recent developments and needed directions. In J. G. Ponterotto, J. M. Casas, L. A. Suzuki, \& C. M. Alexander (Eds.), Handbook of multicultural counseling (pp. 425-456). Thousand Oaks: Sage.

Kluckhohn, F., \& Strodtbeck, F. (1961). Variations in value orientations. Evanston: Rowand Petterson.

Kole, J. (2002). Moral autonomy and Christian faith. A discussion with William K. Frankena. Eburon: Delft.

Koltko-Rivera, M. (2004). The psychology of worldviews. Review of General Psychology, 8(1), 3-58.

Kuhn, Th. (1969). The structure of scientific revolutions. Chicago: University of Chicago Press.

Mackie, J. L. (1977). Inventing right and wrong. Harmondsworth: Penguin Books.

McKenzie, L. (1991). Adult education and worldview construction. Malabar: Krieger Publishing Company.

Miedema, S. (2006). A public, social and individual perspective on religious education. Voices from the past and the present. Studies in Philosophy and Education, 25(1-2), 193-202.

Musschenga, B. (1980). Noodzakelijkheid en mogelijkheid van moraal. Assen: Van Gorcum.

Sandsmark, S. (2000). Is world view neutral education possible and desirable? A Christian response to liberal arguments. Carlisle: Paternoster Press.

Seligman, M. R. E., Gillham, J., et al. (2009). Positive education: positive psychology and classroom interventions. Oxford Review of Education, 35(3), 293-311.

Sire, J. W. (2004). Naming the elephant: Worldview as a concept. Downers Grove: InterVarsity Press.

Smart, N. (2000). Worldviews; cross cultural explorations of human beliefs. Upper Saddle River: PrenticeHall.

Solomon, S., Greenberg, J., \& Pyszczynski, T. (1991). A terror management theory of social behaviour: The psychological functions of self esteem and cultural worldviews. Advances in Experimental Social Psychology, 24, 93-154.

Tillich, P. (1965). Ultimate concern: Tillich in dialogue. In D. MacKenzie Brown (Ed.). London: SCM.

Valk, J. (2007). Plural public schooling: religion, worldviews and moral education. British Journal of Religious Education, 29(3), 273-285.

Van der Kooij, J. C., De Ruyter, D. J., \& Miedema, S. (2013). "Worldview": The meaning of the concept and the impact on religious education. Religious Education, 108(2), 210-228.

Van der Kooij, J. C., De Ruyter, D. J., \& Miedema, S. (in press). The merits of using "worldview" in religious education. Religious Education.

Walsh, B., \& Middleton, J. (1984). The transforming vision: Shaping a Christian world view. Downers Grove: InterVarsity Press. 